\title{
A DIGNIDADE HUMANA DESDE UMA ANTROPOLOGIA DOS INTERVALOS - UMA SÍNTESE ${ }^{1}$
}

Ricardo Timm de Souza*

RESUMO - Este artigo examina a noção de dignidade humana com referência aos temas da temporalidade, singularidade, massa, morte e liberdade ética, no sentido de um projeto de uma nova configuração da antropologia filosófica.

PALAVRAS-CHAVE - Singularidade. Massa. Temporalidade. Liberdade ética. Morte. Antropologia filosófica.
ABSTRACT - This article examines the notion of human dignity in reference to the themes of temporality, singularity, mass, death, and ethical liberty, in the sense of a project of a new philosophical-anthropological configuration.

KEY WORDS - Singularity. Mass. Temporality. Ethical liberty. Death. Philosophical anthropology.

\section{Por uma Antropologia dos Intervalos}

Não se pode chegar com propriedade mínima à noção de dignidade humana sem uma compreensão igualmente mínima do que possa ou deva significar "humano", hoje em dia, ou seja, no tecido complexo da contemporaneidade ${ }^{2}$. Isso significa retomar a difícil tarefa da antropologia,

* Doutor em Filosofia pela Universidade Freiburg im Breisgau, Professor dos Programas de Pós-Graduação em Filosofia e Ciências Criminais na PUCRS.

10 presente artigo, eminentemente sintético, revisita e reelabora idéias constantes especialmente em nosso livro Ainda além do medo - filosofia e antropologia do preconceito, reapresentando a temática de projeto filosófico de uma "antropologia dos intervalos", na qual temos trabalhado em várias oportunidades, especialmente em nossos livros 0 tempo e a máquina do tempo - estudos de filosofia e pós-modernidade; Existência em decisão - uma introdução ao pensamento de Franz Rosenzweig; Metamorfose e extinção - sobre Kafka e a patologia do tempo; Sobre a construção do sentido - o pensar e o agir entre a vida e a filosofia e Em torno à diferença - aventuras da alteridade na complexidade da cultura contemporânea, bem como em artigos isolados e inéditos. Apresentamos algumas dessas idéias sob a forma de 21 teses em SOUZA, R. T. "A dignidade da pessoa humana", in: KIPPER, D. J. (Org.). Etica: teoria e prática - uma visão multidisciplinar, p. $100-132$.

2 Cf. SOUZA, R. T. "Status quaestionis - trauma, história e realidade", in: SOUZA, R. T. Em torno à diferença - aventuras da alteridade na complexidade da cultura contemporânea, p. 3 ss.

\begin{tabular}{|l|l|l|l|l|l|} 
VERITAS & Porto Alegre & v. 53 & n. 2 & abr./jun. 2008 & p. 120-149
\end{tabular}


de todas as antropologias, no precário ponto de instalação de termos por sua vez geneticamente tão complexos como "antropos" e "logos", ambos instados, no exame cuidadoso de sua gênese, a expressarem sua outra face, que tanto submerge numa tensão quase "de gênero", quanto mais não fosse, por sua própria etimologia ${ }^{3}$, como ocorre apesar de toda luz que a visão é capaz de arrojar àquilo que ela percebe como sendo o mundo, e ocorre como vítima de uma determinada configuração do intelecto 4 . E, não obstante, hoje, talvez como sempre, pensar sem antropologia(s) é pior que pensar com ela(s): corre-se mais facilmente o risco de decair no automatismo da racionalidade lúdica ou da intelectualidade perversa.

Todavia, o momento é de reescrita. Antes e acima de tudo, (re)penetrados que estamos pela temporalidade no núcleo da crise civilizatória na qual nos encontramos $^{5}$, não podemos mais dela - da temporalidade - abstrair em nenhum sentido, sob nenhum pretexto, pois "o caminho em direção ao passado é um caminho que não pode ser trilhado"6; a nostalgia do pó dos séculos é sufocante. Em outros termos: não estamos à procura de conceitos fixos, pois aprendemos, pelo menos desde Adorno, a desconfiar profundamente de seu poder de sedução. Não procuramos de modo algum, portanto, alguma tábua inflexível de referência, pois indexações abstratas e axiologias rígidas provaram-se, mais do que inúteis, perniciosas. Desinstalados de qualquer lógica confortável destilada por cérebros poderosos em prol de nossa bonomia, o que nos atinge é o instante no qual nos desencontramos de nossas certezas prévias. Esse é o nosso momento de origem, que aqui arbitramos como ponto de partida do que segue.

Assim, o impulso original da antropologia tal como aqui a entenderemos, seu ponto de partida, numa sugestão altamente heterodoxa, não é nem a possível decisão livre de alguém a respeito de qualquer coisa - aquilo que nos acostumamos a considerar como o especificamente humano em qualquer atitude humana, raiz também de todo iluminismo e de toda iluminação, de todo otimismo racionalista, de todo idealismo humanista, de toda intuição poderosa -, nem, pelo menos diretamente, a constatação dos limites dedutíveis teoricamente em qualquer liberdade possível - aquilo a que costumamos chamar os limites congênitos da condição humana e que todos, sem exceção, percebem e compreendem, pelo menos na hora de sua própria morte. Tudo isso pertenceria ainda ao âmbito essencialista da representação poderosa. Porém, hoje, como nunca na história do pensamento ocidental, o

3 Cf. SOUZA, R. T. "Introdução" a SOUZA, R. T. de. Fontes do humanismo latino - a condição humana no pensamento filosófico moderno e contemporâneo.

4 Cf. SOUZA, R. T. "Da neutralização da diferença à dignidade da Alteridade: estações de uma história multicentenária", in: SOUZA, R. T. Sentido e Alteridade - dez ensaios sobre o pensamento de E. Levinas, p. 189-208.

5 Cf. SOUZA, R. T. Totalidade \& desagregação - sobre as fronteiras do pensamento e suas alternativas, p. 15-29.

6 ROSENZWEIG, Franz. Der Stern der Erlösung, p. 300. 
humano é irrepresentável, e a evocação de seu conceito se depara já com a complexidade que significa optar por determinada concepção de humanidade ${ }^{7}$. Ser humano é ter de mergulhar na inelutabilidade de um momento inconfundível, hipotecar a um instante toda a sua existência, naquela situação específica e única de ocupação. Manter o horizonte indefinido à vista, numa rejeição visceral e completa às seduções do automatismo - eis a permanência inquieta no humano, em contraste com a lógica frenética das máquinas. Contraste não inócuo: é necessário notar que a confusão entre frenetismo e inquietude, corrente hoje em dia, porque sustentadora das grandes lógicas de automatismo da razão instrumental, no qual todos estamos, de certo modo, mergulhados, se constitui em um fulcro excelente de crítica da realidade humana, na medida em que espelha a verdadeira crise de sentido da diferença em seu conceito genérico, banalizado, aquela crise que medeia entre o conceito lógico de diferença e a noção ética de indiferença ${ }^{8}$. É a partir dessa crise, e devido a ela, que é possível perceber como inevitável a necessidade acima referida de uma radical reescrita da idéia de antropologia. Tal exige não uma maior sofisticação representacional, mas um ponto de apoio, uma instância, limitada, porém enraizada, de referência em meio ao próprio tecido indiferenciado, tornado óbvio, da realidade contemporânea, em processo obsessivo de interpenetração de suas imagens e delírios em decadência vital. Tal como a obra de arte, que "só é interpretável pela lei do seu movimento, não por invariantes" $"$, a espessura antropológica não se define por conceitos, mas por sua desinstalação em relação a eles, o que significa finalmente: se define por sua hesitação temporal em contraste com a cronologia do tempo "espacializado".

Vejamos o acima exposto sugerido de maneira diversa, à guisa de ilustração: o ponto de partida da antropologia se constitui no momento preciso e inconfundível em relação a qualquer outro em que uma determinada possibilidade que, tudo indica, deveria ser "livre", hesita em sua maior profundidade, posta-se como existencialmente interditada, definitivamente incompleta: um aborto, o tumulto entre o cronos e o logos que o tempo, simplesmente por se dar, por existir, significa em si mesmo, e não um trilho logicamente percorrido, algum tipo de conciliação espúria entre a temporalidade e a lógica. Em todas as suas dimensões, o momento no qual se dá, por exemplo, o fato inconfundível de que alguém deveria poder caminhar e, por motivos internos, intrínsecos à sua própria condição humana inconfundível com qualquer outra coisa (e não por coerções externas

7 Cf. SOUZA, R. T. "Introdução" a SOUZA, R. T. Fontes do humanismo latino - a condição humana no pensamento filosófico moderno e contemporâneo.

8 Cf. SOUZA, R. T. Sobre a construção do sentido - o pensar e o agir entre a vida e a filosofia.

9 ADORNO, T. Teoria estética, p. 13. 
incidentais) não o pode, ou poderia dever ver e não enxerga, ou sentir e não sente, ou sentir outra coisa do que o que sente -, este momento é o que indicia o primeiro estertor antropológico, é o canal estreito de seu nascimento, é o que dá à luz - redundante o dizer, mas dizemos: definitivamente - a nãoinocência, rompimento do gozo presumido. O intervalo que se define entre qualquer idéia e sua realidade, o intervalo entre o pensado e o que interdita a boa consciência do pensamento, entre o essencial e o aparente, entre o sonho lógico da suavidade e a realidade do atrito, da aspereza - entre o conceito e a realidade - isto é o que circunscreve o embrião da idéia de humano provado pelo tempo. Humano é persistir na existência apesar da decepção, ter de persistir, ter de se manter à distância torturante da perfeição, da idéia perfeita, da realidade perfeita, do afeto perfeito, do sentido perfeito. Para alguns humanos, essa percepção é mais fácil, evidente, agressiva, do que a outros; a todos que não se enxergam como mera ilusão, porém, essa é sua condição inescapável, porque determinante de sua humanidade propriamente dita; tal como a morte é, no dizer de Levinas, a "impossibilidade de minhas possibilidades", essa persistência possível é a impossibilidade dos meus delírios, meu limite que me obriga a ainda durar em sentido bergsoniano. Do choque das durezas cotidianas - modestas ou exaltadas, mas sempre existentes no transbordar de qualquer configuração plana, para além da mera idéia de existência - neste entrechocar-se suave ou abrupto de teores variados de solidez, sobra um caldo: é o humano. Todas as outras dimensões se cruzam nesta, neste instante especial, súbito congelamento do existir em torno a uma claudicação, a uma impossibilidade efetivada que configura exatamente um tempo existente, a contrapartida de um tempo dos relógios. A fuga dessa proto-consciência para o nível de suas interioridades de escape, sua inconsciência, falaciosa porque a realidade foi de uma vez para sempre percebida, cobra altíssimo preço em termos de um mínimo de saúde mental e social. Do ponto de vista da sanidade existencial, ainda é muito preferível não fingir que uma tal proto-consciência não existe, ou é anulável por algum mecanismo intelectual delirante, tais como os sistemas lógicos perfeitos que, ao longo da história do pensamento, se pretenderam substituir à realidade do tempo. "Tempo" é o que me condena à consciência de mim mesmo, em seu nível mais profundo, menos reflexivo; a proto-consciência da hesitação.

O ser que carrega desta forma a aura de sua condenação está às voltas com limites que não se deixam jamais teorizar, pois teorizar seria, neste caso, artificializar um momento da vida mais profunda no instante preciso de derrocada de todo e qualquer artifício: seria negar a realidade. A possibilidade de uma determinada liberdade, ainda que infinitamente precária, nunca está tão presente como no fato dado e inelutável, inegável fora do âmbito da demência, da não-efetivação de si como uma liberdade 
possível, por mínima que seja ${ }^{10}$. E, mesmo no âmbito da demência, em algum campo de loucura lúcida que multiplique infinitamente as possibilidades, ainda ali exorbita o peso do instante apesar da loucura, na loucura; a insanidade não é pretexto para que alguém consiga escapar a um terremoto devastador.

Assim, ser humano é ter de viver no tempo sonhando com o paraíso perdido da eternidade sem tempo, ou seja, o próprio do humano é a distância irremissível entre tempo e eternidade. A criança que apareceu no mundo que percebe, que se percebeu definitivamente circunscrita a uma forma que não definiu a priori, uma forma estranha e pesada que está nela, que é ela, a criança que se percebeu um corpo precário mas pesado, existente muito antes que compreendido (na hipótese extremamente otimista da compreensão), um corpo já dado, já passado, incômodo por natureza, desajeitado, que sentiu na carne a distância intransponível entre sua vontade de onipotência e sua fragilidade efetiva, essa frustração original e definidora de todas as consciências ulteriores, esta criança percebeu, de uma vez para sempre, o essencial pensável da humanidade, já acima sugerido: o intervalo inelutável entre o existir determinado e o autoprojeto, a autoconstrução segundo a vontade absolutamente desimpedida e a liberdade ideal, que nunca será realidade, pois seu tempo já passou e ela não aconteceu. Essa é igualmente a razão pela qual todo sistema filosófico, em qualquer época, com pretensão de completude, de totalidade, está destinado a fracassar, pois não consegue englobar em si as razões de sua própria existência como se depreende, hoje, na herança do século da temporalidade e da finitude, na esteira, por exemplo, de um Kierkegaard; não se pode, sem violência, abstrair da existência temporal prévia da multiplicidade dos sentidos a pretexto da transformação da diferença real, origem de toda realidade pensável, em diferença lógica, momento ou estrutura interna de articulação de uma Totalidade ${ }^{11}$. Ser humano é ser nostálgico, álgico - e, por isso, a anestesia, vida suspensa, é uma espécie de detenção do humano -, ter de suportar na profundidade dos tecidos a dor de um futuro pleno que nunca poderá ser construído. Vita brevis, ars longa: máxima antropológica entre as fímbrias da consciência, o descompasso entre a efetividade do disponível e a indisponibilidade definitiva do ideal, eis o que marca, de uma vez para todo o sempre, todo resíduo de humanidade que possa habitar em cada um, independentemente do que pense ou faça. É o que faz com que a humanidade viva, no fundo, em um admirável conluio, um comprazer-se

10 Cf. SOUZA, R. T. "Brevilóquio sobre a liberdade ética", in: SOUZA, R. T. Em torno à diferença aventuras da alteridade na complexidade da cultura contemporânea, p. 185-187.

11 Cf. ADORNO, T. Negative dialektik; SOUZA, R. T. "Da neutralização da diferença à dignidade da Alteridade: estações de uma história multicentenária", in: SOUZA, R. T. Sentido e alteridade - dez ensaios sobre o pensamento de E. Levinas; SOUZA, R. T. Totalidade \& desagregação. Sobre as fronteiras do pensamento e suas alternativas. 
das mútuas finitudes e delírios, culpas e desculpas, consciência e inconsciência, variedade inominável afeita a um só termo final, a um só espaço para além das mais sofisticadas concepções de espaço: o espaço que existe entre a vontade e a realidade, entre tempo e eternidade, espécie de crise original, sofrimento em nível crítico. Assim, o mundo humano, ou seja, o humano como referência de sentido (e não origem de sentido), se dá como o oposto daquilo que o senso comum considera o mundo "objetivo", o mundo bem organizado, com cada coisa em seu lugar, "de laboratório", ou a desabitada nebulosa de Laplace ${ }^{12}$, que a ciência tradicional e as mais diversas ideologias se apressam em seqüestrar para seus propósitos estratégicos. E não é sem razão que o propriamente humano, em seu acontecer e não em seu mero pensar, se apresenta como alternativo ao cosmos. Humanidade é incompletude qualificada, com suficiente consciência para se auto-perceber precisamente como e enquanto incompletude.

Estamos aqui em um vasto caudal contemporâneo de rearranjo de significantes. No espectro da falência civilizatória da idéia de representação ${ }^{13}$, idéia hoje quase sempre ausente em âmbitos muito precisos da racionalidade estratégica, como a mídia, é propícia uma revisita ao hoje precário, porém sempre atraente, par lógico objetividade-subjetividade.

O exame desse par lógico deve iniciar pelo exame da idéia de objetividade. O que seria um mundo "objetivo"? Um mundo antes de tudo ideal, pois se constitui primariamente no objeto de uma racionalidade que o pensa - fenomenologicamente, à Husserl, diríamos: que o intenciona idealmente como mundo, porém, para além do Husserl da fenomenologia estrita, deveríamos dizer: que se circunscreve em um âmbito de validade cuja demarcação é exatamente o contraste com a realidade de quem o pensa -, e, nestas circunstâncias, irreal. Irreal, em outros termos, por se constituir em uma espécie idealizada de aversão às determinações da existência, como se, para existir, tivesse que hipotecar toda sua densidade a uma paradoxal negação do contato com quem pretende percebê-lo. $O$ dado que o próprio mundo, os muitos mundos, nos ensinam, é exatamente que não existe nenhum mundo, no sentido humano do termo, que não tenha sentido propriamente humano (assim como não existe ciência que não seja humana, o que significa, feita por humanos para humanos). Ou, em outras palavras, é exatamente porque tem sentido no contexto especial de um determinado mundo humano, anterior, primordial, que qualquer mundo concebível pode ser concebido com sentido e não como uma fábula impossível ou como um círculo quadrado. Se concebemos um planeta tão distante que ninguém jamais lá esteve, negamos ao mesmo tempo sua possibilidade enquanto desabitado, pois, de uma forma muito sutil, prévia à vontade do intelecto, já

12 LUIJPEN, W. Introdução à fenomenologia existencial, p. 69.

13 Cf. SOUZA, R. T. "Status quaestionis - trauma, história e realidade", in: SOUZA, R. T. Em torno à diferença - aventuras da alteridade na complexidade da cultura contemporânea, p. 3 ss. 
o habitamos com nosso espírito, já o contaminamos com nossa humanidade, pois já o concebemos. Assim, o perfeitamente objetivo só cabe em uma formulística de correlação que ignora a própria corporeidade intencionalexistencial primária, no sentido de Merleau-Ponty. Nossa visão é poderosa, porém contaminante; ignorar esse dado é fatal para as boas intenções da racionalidade. Essa visão, que se apresenta ao intelecto como representação, carrega em si dimensões de onipotência que há que desconstruir, se quisermos reconhecer o real para além da idéia de realidade ${ }^{14}$.

Tal se passa de modo eminente - e aqui chegamos ao ápice da presente tensão reflexiva -, no que diz respeito à relação entre intelecto e tempo. Se concebemos um passado extremamente antigo, ainda assim ele será, enquanto concebido por nós e exatamente por isso, "presentificado ao presente", pensado em seu presente específico, ainda que remoto, ocorrido então, em sua própria presença, e não em seu passado propriamente dito: ocorre uma sincronização de presenças; sua figuração é pertencente, de forma sutil mas real, ao nosso espectro de determinações. Não há, na racionalidade calculadora, nenhuma possibilidade de conceber o passado como passado, o tempo como tempo, mas apenas de presentificar tudo de si para si e de si para nós, ou seja, uma presentificação de segunda ordem; é por isso que não há o que permita que concebamos uma paisagem jurássica, por exemplo, no seu e no nosso passado, mas apenas no seu presente representificado na nossa representação, no nosso pensamento atual quando a pensamos - aquilo que concebemos como extremamente antigo é elevado, por essa concepção mesma, a uma espécie de exponencial de sua "presentidade": a paisagem na qual pensamos está totalmente presente a si mesma, "para si" e para nós. E isso por uma razão simples; pois o caminho já trilhado é um caminho que não pode ser novamente percorrido, apenas re-presentado. Isso significa levar o tempo a sério. Eis, portanto, a síntese: todos os mundos humanamente concebíveis, enquanto de uma forma ou outra subjetivamente concebíveis, estão contaminados de humanidade, como todo Nada está contaminado de Ser; pois o Nada é, ao menos, nada.

Assim, "quem compreende que o mundo e a verdade sobre o mundo são radicalmente humanos, está preparado para conceber que não existe um mundo em si, mas muitos mundos humanos, de acordo com as atitudes ou pontos de vista do sujeito existente. O homem é essencialmente existência e isso acarreta que a significação do mundo se diferencia conforme as várias atitudes ou pontos de vista do sujeito-no-mundo"15. Chegamos aqui, pela fenomenologia, à multiplicidade como origem de sentido, na direção proposta por Rosenzweig ${ }^{16}$. O ser humano é concebido em um mundo humano entre

14 Cf. SOUZA, R. T. "O assassinato e o fracasso original", in: Sentido e alteridade - dez ensaios sobre 0 pensamento de E. Levinas.

15 LUIJPEN, W. Op. cit., p. 76.

16 Cf. SOUZA, R. T. "Rosenzweig e a razão múltipla", in: SOUZA, R. T. Razões plurais - itinerários da racionalidade ética no século XX: Adorno, Bergson, Derrida, Levinas, Rosenzweig. 
muitos outros, nasce em um mundo humano entre muitos outros, vive em um mundo humano entre muitos outros: é um mundo humano entre inumeráveis outros; e essa multiplicidade não lhe é acidental, mas constitucional; constitui-se na dialética semelhança-diferença com tudo o que o transcende. Aí, no fulcro da diferença existencial, na expressão da multiplicidade incontornável coagulada em torno a um pólo de sentido que, mais tarde, poderá vir a se tornar singularidade ou sujeito -, se inicia sua fisiologia e se definem seus intervalos existenciais, os espaços próprios de sua validade, ou seja, sua existência intervalar, seu "valer-entre", intervalos esses que se estabelecem fundamentalmente no campo de uma tensão entre permanência e impermanência, portanto temporalidade. O ser humano nasce no mundo, com o mundo, como mundo. Sobrevive-se ao próprio nascimento não, pelo menos não apenas, pela solidez de si próprio, mas pelo espaço disponível à multiplicidade, que, por sua vez, define aqui, metodologicamente, a própria noção de espaço: espaço é a possibilidade de a multiplicidade se dar.

O início, a gênese, é a ex-posição de uma face ao externo: é sua diferença com relação ao que não é ela; no princípio, é sempre a diferença ${ }^{17}$. Assim, a primeira constatação é de ordem estritamente empírica, e não especulativa: o minúsculo embrião já é humano e, mais, delimita já o humano na medida em que o "abre" ao seu "além", ao que não é ele, é uma face ex-posta ao externo: não é a placenta que o envolve, nem o sangue materno que o alimenta, nem o útero que habita. Sua solidez é definitiva, pois "o caminho em direção ao passado é um caminho que não pode ser trilhado"18: separouse de uma vez para sempre da indeterminação. Ainda que logo morra, seja abortado, odiado, trucidado, seja reduzido a pó ou a nada; sua mancha existencial, sua passagem do possível ao existente, ao real, é indelével, ainda que, em termos das lógicas de violência, olvidável nas penumbras da história. Existiu uma vez, e esta existência, incrustada para sempre no campo do real, vincada eternamente pela separação definitiva, por mais fugaz que esta tenha sido, não pode ser desarticulada do conjunto de todos os fatos do passado, e isso não no sentido das contas de um colar, mas no sentido de um turbilhão de acontecimentos. Ali já se deu, no campo do mais estritamente humano, o primeiro grande e definitivo para-doxo existencial: a característica e já referida interpolação entre tempo e eternidade, essa questão protofilosófica, que se repetirá infinitamente ao longo da curta vida do novo ser o qual habitará exatamente o estreito espaço que se desdobra entre o instante fugaz da inauguração de sua separação, de sua existência, e os domínios da eternidade, estrangeira aos seus tecidos e, em última análise, alheia à

17 Cf. nosso artigo cit. "Da neutralização da diferença à dignidade da Alteridade: estações de uma história multicentenária", in: SOUZA, R. T. Sentido e alteridade - dez ensaios sobre o pensamento de E. Levinas.

18 ROSENZWEIG, Franz. Der Stern der Erlösung, p. 300. 
sua dolorosa facticidade, e ali valerá, inter-valerá. O bebê nasce grave: seu peso é enorme, embora leve a quem o segure; sua espessura é a negação da mera idéia, nada tem de leviana, reafirmando sua separação, sua congênita e definitiva imiscibilidade com o meio e com os outros; ainda a mais desvairada e patológica osmose entre mãe e filho não conseguirá que a mãe sinta as dores do filho em sentido próprio; talvez a maior dor da mãe seja, exatamente, não poder sentir a dor do filho. Todo o itinerário subseqüente da consciência em formação, suas idas e vindas, seus desejos e hesitações, seu desenvolvimento no sentido de sentir-se mais e mais autônoma e separada, não é mais do que o reencontro com um factum original. O espasmo é para sempre, e a primeira conclusão, que conclui o nascimento, é definitiva: a intrusão na ordem da realidade é irreversível.

\section{(Interregno - a morte antes do nascer)}

"Quando deixei o hospital militar americano, voltei a Roma e fui alojar-me em casa de um amigo meu, o Dr. Pietro Marziale, médico obstetra [...] A casa era pequena, e coube-me dormir no gabinete, num divã. Ao longo das paredes do gabinete corriam prateleiras cheias de livros de ginecologia, e nos bordos dessas prateleiras alinhavam-se instrumentos de obstetrícia, tais como fórceps, ferros, bisturis, érinas, tesouras recurvas, dilatadores, espéculos, pinças de todos os feitios; e frascos de boca larga cheios de líquido amarelo. Em cada frasco estava mergulhado um feto humano. [...] Há muitos dias que vivia entre aquela população de fetos, e o horror oprimia-me. Pois os fetos são cadáveres, mas de monstruosa espécie: são cadáveres que nunca nasceram, nem nunca morreram [...] alguns tinham o ar pensativo de um afogado... outros entretinham-se em saltar à corda, com a longa fita branca do cordão umbilical. Outros ainda estavam sentados, acocorados numa imobilidade vigilante e suspeitosa, como se esperassem entrar na vida de um momento para outro. [...] E tinham, todos, o ar velho de homens ainda não nascidos e que nunca nascerão. Estavam diante da porta fechada da vida, como nós estamos diante da porta fechada da morte [...]"19.

\section{Singularidade}

Assim, a aventura humana é o reencontrar-se perpétuo com sua singularidade, cujo fracasso significa, de algum modo, a denúncia do fracasso da vida, o que resta de uma morte inútili ${ }^{20}$ que se segue a um "sofrimento inútil", no dizer de Levinas - um "perpétuo enquanto dura", um perpetuum mobile pulsante, hesitante, porém reiterado, sofrendo de crônicas dores do atrito com o externo, face ex-posta, neurotizando-se e se desneurotizando, mantendo sempre à vista a tentação do abismo - Ab-grund - e da loucura, navegando entre patologias possíveis e reais, fechando-se e se abrindo,

19 MALAPARTE, Curzio. A pele, p. 294-296.

20 Cf. SOUZA, R. T., "A vida opaca - meditações sobre a singularidade fracassada", in: OLIVEIRA, N. F.; SOUZA, D. G. (Orgs.). Hermenêutica e filosofia primeira, p. 461-469. 
lutando para permanecer à superfície da permanência na vida e regozijandose, em ansiedade permanente, com tal esforço: mobilização de energias esperançosas, respirando - aventura indescritível, única escapatória da depressão da existência. O que é a criança do ponto de vista do tempo? A expectativa que o tempo se realize, ou, em outros termos, a expectativa de ter tempo para "tornar-se o que é"; todos os seus constitutivos, a biologia de seus órgãos e sistemas, é tempo de espera, a sua filiação à humanidade biológica, mão que é esperança de segurar algo, olhos que são expectativa de ver, ouvidos de ouvir, pulmões de respirar, pés de caminhar. A criança é a esperança do tempo. A forma como essa esperança se desenrola na cronologia dos acontecimentos é a aventura da criança por excelência: navegar entre sustos e descobertas; experimentar na pele a aspereza do mundo; endurecer-se sem se desfragilizar; duvidar de suas forças e ter de conviver com suas fraquezas; experimentar o novo e ter de adequar-se ao fluir do tempo: sentir em si o atrito da realidade, sentir-se um mundo e aprender a encontrar, nas profundidades deste mundo, uma consciência refletindo-se na palavra, na expressão de sua unicidade - pois toda palavra, especialmente a primeira que a criança emite, é exatamente isso: protopalavra, dizer originário, expressão da unicidade radical - não existe palavra indiferenciada, por si só uma contradição em seus termos. Toda palavra é sempre primeira palavra, porque é a palavra da diferença, sua razão de surgir. Crescer significa superar cada fragmento de contingência que se interpõe entre o agora e o próximo cintilar de vida: auto-superação, permanência impermanente. É por isso, entre outras razões, que há mais humanidade na capacidade de superação de certos deficientes físicos, por exemplo, do que todas as epopéias e odes à grandeza humana que já foram compostos: expressam a superação em seu estado mais puro, sem a constelação de idealizações que orna as grandes obras artísticas e literárias. Humano in extremis, o deficiente que se supera é a expressão mais inequívoca do núcleo próprio do humano - sem os disfarces e a embriaguez da excitação da Idéia, o que, se é bem verdade que também dá ao humano elementos de sua especificidade, acaba por criar com o passar do tempo, ao menos potencialmente, um mundo paralelo, uma mania de grandeza, onde podem se refugiar muitos medos, negando assim faticamente o essencial do eterno e paradoxal recomeçar - um recomeço constante do sentido - que caracteriza a humanidade despida de seus adereços suavizantes. Crescer é dar-se crescentemente conta, em sua unidade, de sua radical unicidade, unicidade que só existe no instante de decisão de seu acontecer e a partir daí, o resto do tempo, o tempo que resta.

\section{Massa}

Porém, viver é também dispersar energia, e não apenas concentrá-las. A dispersão é a inconsciência do existir, o mergulhar de retorno no limbo do indiferenciado artificialmente recriado. A dispersão, a desatenção ao 
instante, leva fundamentalmente a uma conseqüência fatal; a unidade e a unicidade são negadas: compõe-se a massa. Massa, indiferenciação, miríade indiferenciada de fragmentos de nada, é a contra-dição do dizer primeiro, sua submersão nas tonalidades indistintas, primeiro e violento espasmo da Totalidade, mundo primevo e sem diferenciação, caldo primitivo, fecundo apenas nas aparências, baseado na segurança monolítica: sem intervalos. Seres individuais, diferenças, renunciam à sua origem precisa, particular, inconfundível, e agrupam-se em massa compacta: a massa é a ideologia concreta e concretizada, a primeira espessura indiferente. As diferenças, no massificar-se, declinam de toda dignidade: delegam-na à indiferença. Criam a política, e tentam imediatamente destruí-la, quando a percebem como um possível recurso de emancipação e crítica da tautologia. Passamse mutuamente um atestado de inépcia existencial e coletivizam-se. Vivem por procuração. Proliferam, e, ao proliferar, ao multiplicar sua mediocridade, negam aquilo que procuram ainda que não o saibam: a dimensão sóciosolidária. Engendram preconceitos de todos os tipos, imagens retorcidas e desmesuradamente infladas de seus próprios medos ${ }^{21}$. Enxergam-se em suas projeções. Disseminam-se e, ao se disseminar, negam o novo; no automatismo desenfreado da multiplicação, tudo é já antigo, tautológico, pesadamente massivo. Deliram em uma febre fátua e evanescente. Abdicam do espaço da realidade possível: ocupam um espaço excessivo, onde o potencial não tem vez, apenas as passadas de elefante da grande Ideologia, do excesso de ser. Nessa lógica, o pequeno, o fraco, o improvável, todos desaparecem: não deveriam ter nascido. Apenas as grandes respirações, estertoradas, podem ser ouvidas. Sua grande esperança é não necessitar ter esperanças, poder chegar rapidamente ao fim da História e de todas as histórias; sua gloriosa utopia é fazer da Utopia - do não-lugar, do ainda-não - algo demais para sempre.

\section{Unicidade}

Mas, apesar de tudo, a perspectiva pela qual cada um cresce, percebe o sentido ou o significado, pelo menos, do investimento existencial na busca de sentido, vai caracterizar a unidade do procurante de forma inequívoca e isto ainda antes que a consciência destes fatos esteja disponível. Pode-se romper a massa. Pois cada perspectiva - da qual o desdobramento concreto em busca de algo realmente significante é a expressão mais clara - é perfeitamente única, credora de um mundo humano particularíssimo, inconfundível, de uma perspectiva que nunca houve e que nunca se repetirá, e caracteriza a unidade e a unicidade das humanidades particulares. Unidade, no sentido de que há no humano uma irrepetível interpenetração e um entrecruzamento de significados que, instantâneos em sua origem,

${ }_{21}$ Cf. SOUZA, R. T. Ainda além do medo - filosofia e antropologia do preconceito. 
assumem necessariamente uma feição durável, compondo um todo menos frágil, menos efêmero que os instantes que compõem sua matéria-prima, e onde estes instantes se fazem presentes de forma muito particular. Unicidade, porque esta unidade, este mundo, é cabalmente irrepetível, assumindo assim um valor inigualável, não-reproduzível ainda que pelo ourives mais delicado ou pela mais sutil manipulação genética. Uma vez para sempre, mas apenas uma vez: eis a essência do drama humano, sua incontornável solidão essencial, solidão igualmente irrepetível. $O$ jogo da existência não se dá abstratamente, mas, apenas e definitivamente, no processo de interpenetração e mútua fecundação de existências únicas. A unicidade humana é o resultado da tensa dialética entre o gozo e o sofrimento, dialética essa expressa na incomunicabilidade profunda das experiências vitais; a ninguém é dada, em verdade, a habilidade real em penetrar na unicidade de outrem (seja qual for o poder empático envolvido no processo): a con-fusão, a fusão dos únicos em uma unidade de sentido, é negação do especificamente humano e, portanto, em última análise, a negação da possibilidade da própria humanidade. Negar a (con)fusão é tomar consciência da própria morte, verse envolvido, unicamente, por sua própria unicidade.

A unicidade não é apenas solidão; ela é, também, gozo de solidão, gozo em solidão - a anti-massa em sua primeira expressão ${ }^{22}$. O ser que se desenvolve em um determinado sentido só seu, que preenche completamente sua silhueta, conquista um estatuto próprio, apenas porque foi si mesmo, uma centralidade de referência de sua própria dinâmica. Neste segundo, absolutamente ninguém o acompanhou (muito embora possa haver alguém que tenha admirado a façanha, a uma distância mínima, mas não congruente: isso é a vida comunitária, ou a paternidade e a maternidade) - uma tarefa solitária por excelência. Se é verdade que o ser humano se alimenta de ingenuidades, esta é uma instância privilegiada delas: a solidão é o primeiro gozo possível, raiz de toda fruição, ainda das não-solitárias. O ser às voltas com suas conquistas está primariamente ocupado consigo mesmo, reafirma seu próprio verbo e reifica de alguma forma a realidade que o circunda, alimenta-se dela, a objetiva dentro de um determinado contexto particular: lida com sua sombra. Esta é sua ingenuidade mais original, que é também o seu primeiro engenho: perceber-se, comprazer-se, julgar-se só em meio à infinidade de mundos e coisas; mas é uma ingenuidade grave, de conseqüências sérias, que obriga irrevogavelmente ao assumir da unicidade, pois é, em fim de contas, essa unicidade mesma, essa inconfundibilidade, no paradoxo do prazer eivado de desprazer e vice-versa, um paradoxo legitimamente humano, o que significa: assombrado pela morte que vem.

A unicidade congênita de cada ser humano tem assim uma dimensão de prazer originária, combinada ab initio com o peso de tal fato. Todo prazer

2 Cf. SUSIN, Luiz Carlos. O homem messiânico. Uma introdução ao pensamento de Emmanuel Levinas. 
de tal ordem existencial é por definição não-multiplicável e irrepetível; as elaboradas construções posteriores no sentido do compartilhamento do prazer não seriam absolutamente necessárias, caso a mais intensa solidão não acompanhasse intimamente a própria gênese da unicidade - e esta solidão é o imenso preço que se paga pela definitiva irrepetibilidade do humano.

\section{As falácias da liberdade burguesa}

Essa solidão nascente porta, porém, já desde o início, a possibilidade do retrógrado que simula o retrilhar de seu próprio caminho, que simula essa possibilidade - "pois o caminho do passado é um caminho que não pode ser trilhado" - de modo elaboradamente crível, em coincidência com sua falsidade original, porque negador de si mesmo. Para tal, cumpre paralisar o tempo ou, o que dá na mesma, esterilizar a solitude do inconfundível naquilo que ela tem de fecundo: a capacidade, pelo tempo, de não se contentar apenas consigo mesma.

A marca da liberdade burguesa é a solidão paralisada no tempo. Nascida em uma época, em um momento específico da história ocidental - o vivenciar das revoluções burguesas e de suas justificações -, petrifica-o, e o re-enuncia ad nauseam, como se as condições dadas àquela época perdurassem igualmente. De algum modo, tudo o que não é si mesma, ou seja, tudo o que não preserva sua habilidade ou capacidade de estabelecer livremente contratos com as outras liberdades que poderiam não existir (diferentemente da existência humana concreta, onde cada um nasce na multiplicidade e nada é fora do contexto de relações que o constituem), com os outros lógicos que habitam o mundo lógico que a circunda como seu mundo de referência, é determinado como não podendo existir, ou, mais freqüentemente, é subsumido na sua própria realidade totalizante, no seu fluxo trófico ${ }^{23}$. Porém, esse fluxo trófico, a totalização e suas propostas de Totalidade, encontramse estruturalmente abaladas por argumentos que não provêm de algum "mundo das idéias", mas da realidade socioecológico incontrolável pelas meras idéias: argumentos por assim dizer, materiais e não formais ${ }^{24}$. Essa é a razão pela qual, em um momento depressivo da cultura, não é possível haurir novas energias argumentativas para a apologia da liberdade burguesa, e explica porque seus defensores não têm outra saída senão voltar às épocas de seu nascimento para reapresentar seus argumentos, como se, na física, estivéssemos ainda exclusivamente no universo newtoniano de referência ou, na literatura, o ápice de atualidade a que houvéssemos chegado tenha sido o romance balzaquiano, ou ainda, na música, a vanguarda correspondesse ao tardo-romantismo de um Tschaikovski.

z3 Cf. SOUZA, R. T. de. Totalidade \& desagregação - sobre as fronteiras do pensamento e suas alternativas.

24 Cf. SOUZA, "Alteridade e ecologia - por uma nova ética ambiental", in: CLOTET, J.; FEIJÓ, A.; OLIVEIRA, M. G. (Orgs.). Bioética - uma visão panorâmica. 
Não é aqui lugar de análise de clássicos sobejamente conhecidos na história da filosofia que justificam este modelo de concepção de mundo. Interessa-nos muito mais compreender de que modo esta marca de solidão paralisada no tempo e, por decorrência, refreada em seu potencial de estabelecimento de relações para além das meramente lógicas, se estatui como a dimensão não somente desejável, mas pretensamente única possível, na cultura hegemônica da modernidade ocidental, pelo menos até a sua decadência teórica a partir de meados do século XIX (os teóricos que a defendem ainda hoje, como já referimos na esteira dos clássicos, nada mais fazem do que requentar a retónica otimista daqueles séculos que antecederam a grande depressão cultural-civilizatória dos séculos XIX e XX). E isso por uma razão muito simples: porque essa compreensão é a única possibilidade de, por sua vez, compreender propriamente a crise civilizatória de que somos herdeiros nesse início de século XXI. Vivemos hoje, literalmente na carne dos tempos, a falência de promessas de felicidade não cumpridas; é isso que caracteriza os estratos subterrâneos da crise de sentido que habita o interior das consciências que cederam à tentação das massas, o que significa hoje, essencialmente, a constituição de complexas máquinas - maquinismos, mãos invisíveis de conseqüências bem visíveis - de exploração da natureza e do Outro. Desse modo, em termos mais amplos, pode-se afirmar que a liberdade burguesa se constitui congenitamente em uma falácia pelo seguinte motivo: para se afirmar, tem de deter o acontecer do tempo, isolando-se logicamente em mônada de sentido; a auto-compreensão monádica resultante deste processo não consegue conceber o mundo externo senão à sua imagem e semelhança, ou seja, constituído de outras infinitas mônadas, perfeitamente isoladas umas das outras, infinitos habitantes lógicos de um espaço lógico. Essa é a condição para que se constitua a idéia de contrato, que habita, implicitamente, todas as relações sociais - e nos referimos, aqui, a "contratos mentais", anteriores até mesmo às mais vulgares das idéias contratualistas - porque se apropriou da própria noção de humanidade, formalizando noções que designam conteúdos cabais que não existem fora de sua realidade concreta, como "ética" e "justiça". Para esta concepção de mundo, ética e justiça nada mais são do que o equilibrado estabelecimento de contratos ou a restauração de seus danos, independentemente do fato de esses existirem ou serem possíveis - em suma, como se eu devesse agir bem para com um bebê indefeso porque ele é, de certo modo, "igual" a mim, entidade poderosa e determinante, e não, exatamente, porque ele é tão diferente de mim que é irredutível a qualquer conceito correlato de equilíbrio. Quando se conseguiu transformar a idéia geral de justiça na idéia geral de equilíbrio - um sonho tão antigo como a própria humanidade ocidental, mas que apenas na modernidade floresce plenamente - conseguiu-se extrair da idéia geral de justiça exatamente o que constitui a sua dimensão essencial, ou seja, a necessidade de se fazer justiça ao outro que habita outro tempo, para além de minha capacidade 
lógica de síntese e de pretenso entendimento de sua realidade. Confundiuse o meramente moral com o existencialmente ético, e o legal com o justo; e, assim, na esteira das formalizações, foi possível que se criassem condições para que se suporte que, exatamente no auge de uma retórica formal de "igualdade", as maiores desigualdades reais possam ter plena vigência como se fossem meros "acidentes de percurso", esse paradoxo enlouquecedor para qualquer criança que capte o simples acontecer do mundo que a cerca, mas que parece incapaz de abalar os construtos mentais de pensadores que não fazem senão procurar atenuar a percepção da profunda indecência que habita “...uma razão que nós não aceitamos mais, ... uma aparência de sabedoria que nos causa horror, ... uma oferta de acordo e de conciliação que nós não entendemos".

Desse modo, um ato subjetivo humano se constituiria, segundo a linhagem hegemônica do pensamento filosófico da modernidade (o qual traduz um impulso muito mais antigo), pelo assumir altaneiro do Cogito e pelo seu traduzir em ação; conquisto, penso, existo, ajo, determino, defino a baconiana "coincidência essencial" entre saber e poder - eis a ordem natural tanto do racionalismo e das escolas filosóficas a ele de alguma forma filiadas como daquelas suas aparentemente antípodas, como os diversos modelos de empirismo, e que traduzem o peso histórico de uma época de autodescobertas: uma passagem do especular, do jogo de espelhos, à especulação filosófica e ao agir prático através do domínio da natureza e do Outro como panegírico da parmenidiana história do Mesmo com sua falácia primeva; a pretensa coincidência entre ser e pensar. Constitui-se, de qualquer modo e em nuances diversas, uma subjetividade racional, única às voltas com sua verdade, prévia ao questionamento do correr do tempo, por estar de algum modo, por aferrada às seduções da cronologia, fora do tempo. Repousa na eternidade dos conceitos livres: é já uma determinada expressão de liberdade nos moldes acima descritos ainda antes de o saber, confunde-se com o próprio conceito de liberdade, e se desdobra em seu constante reencontrarse em suas afirmações, na univocidade de uma linguagem referente à eternidade dos conceitos. Identifica-se com uma determinada forma de vontade: aquela que constitui o núcleo do processo de concentração de sentido junto a um pólo de referência. Esta é a subjetividade moderna, mas não apenas ela: esta é a forma que, de uma forma ou de outra, tomam todas as especificações e modalidades de subjetividade baseadas no isolamento epistemológico de sua autodefinição e auto-sentido - ou seja, esta é a forma que acaba assumindo, cedo ou tarde, a concepção de subjetividade baseada na auto-compreensão da mônada (aqui, como se depreende facilmente, entendida como indivíduo moderno), sem a concorrência de outras subjetividades paralelas, dialogantes, conviventes, questionadoras de uma posição decisória. A marca da vontade, do sentido, da razão e da subjetividade da mônada é sempre, ao início como ao fim, o vinco da solidão paralisada no tempo, a razão solitária, especular-especulativa, matéria-prima 
da razão difusa das massas. Esta consciência subjetiva revela-se, assim, como pseudoconsciência: para ela não existe o Novo, mas apenas o medo mortal dele, porque a temporalidade, formalizada em cronologia, poderia irromper exatamente por causa do surgimento do novo, (única) oportunidade de realização da justiça. $\mathrm{E}$, desse modo, tudo o que dela deriva padece da ilusão da possibilidade do exorcismo da temporalidade real. Essa ilusão seria apenas patética, não fosse trágica quando traduzida faticamente na violência que expressa a verdadeira face da vontade de poder. A liberdade burguesa e suas retóricas, o elogio da solidão, apologia da massa onde cada um deve se sentir absolutamente solitário, porque é intercambiável com qualquer outro sem que tal substituição se faça notar (a massa é a anulação perfeita da singularidade e do inconfundível, animal amorfo com vida própria, emprestando, todavia, a cada peça intercambiável a ilusão da pertença), é o braço ideológico das infinitas faces de violência que saturam o mundo e a história contemporâneos.

\section{O morrer e a suspensão da obviedade}

O ser humano é, assim, o ser que perdura, mas o faz hesitantemente, às voltas com as tentadoras tentações do reacionarismo das idéias e com a excitação catalisada por um existir temporal que se renova, sem poder nunca abandonar os domínios da surpresa - e sem poder deixar, enquanto propriamente humano, de perdurar. Flutua entre estes dois espectros, neste intervalo de realidade. Este é seu contraponto original. Sua duração interpenetra-se constantemente no campo da hesitação: está condenado a permanecer sob o domínio da impermanência ameaçadora. A cada êxtase de duração, a cada segundo sobrevivido, corresponde um igualmente intenso calafrio de hesitação, como se a realidade como um todo se organizasse de tal forma que o instante, conquistado a duras penas, nada mais fosse do que uma ilusão bem medida, ou a antecâmara da queda final e definitiva: eterno sobressalto.

Mas o vencer o instante pelo próprio assumir do instante - vencer a inexorabilidade do tempo pela via da duração, da crença na duração do que efetivamente não se entrega ao poder sublimador da idéia - reorganiza a unidade e lhe dá um frescor sempre novo, anti-inercial: algo fundamental, pois a inércia é uma das características principais da massa.

Assim, a existência se distribui ao longo de inumeráveis pequenos intervalos existenciais, mais ou menos indefinidos enquanto mônadas contáveis, qual elos de um infinito colar mais ou menos indefinível, obscurecidos por sua não-mais-existência, revividos pela memória cuidadosa, pela vontade feita lembrança. O existir projeta-se em todas as direções: amplia espaços, antevê tempos, relaciona mundos, documenta estas relações coletivas e individuais, constrói grandes edifícios de ousadia, pode enxergar em si mesmo a vivência da glória e do poder: seus intervalos dilatam-se forçadamente cada vez mais, atropelam-se, consubstanciam-se 
na solidez das convenções, oferecem recompensas gratuitas, simplificam a seus olhos a complexidade infinita dos mundos humanos mais diversos aniquilam o diferente. Certos lugares-comuns absorvem a tônica da vida, apresentam-se como síntese da possibilidade mesma da existência humana, recheiam o ser originalmente indigente, intervalar, de absolutos, de essências diversas, todas elas puras, todas elas auto-justificantes, formalidades ocas: todos os delírios têm, então, espaço garantido no universo das tentações. A maior de todas as tentações se mostra então: a de conquistar totalmente a infinitude das realidades concretas, particulares, através da demiurgia do absoluto, da abstração absoluta do Todo, da vontade de sistema perfeito, Aufhebung perfeita da realidade parcial, imperfeita, relativa, intervalar, na perfeição da Totalidade de sentido, pela vontade de poder.

Assim, em outros termos: a tentação da abstração absoluta - pretensa purificação da realidade dada e vivida - é a raiz de todas as violências, raiz da abstração das circunstâncias, do desejo da transformação alquímica dos infinitos mundos humanos em apenas um mundo, um mundo com sentido absoluto, na obviedade do opaco ${ }^{25}$. Subitamente, a duração é, apenas, a oportunidade da definição deste sentido absoluto: só tem sentido enquanto chance de encontro com o total, com a Totalidade. Até a mais excitante aventura é potencialmente tediosa; a sucessão infinita de momentos irresolvidos irrita a dimensão do ser em contato com a realidade. Houve progressos, houve sobrevivência: este é um fato considerável. O encontro reiterado, pesadamente real, com o Diferente, com o Outro ainda não explicado pelo intelecto, de contornos sempre imprecisos em meio às franjas de minha subjetividade, o Outro escuro, nas sombras, entremeado de inconsciência desde o ponto de vista de minha consciência, a nebulosidade das fronteiras de minha vontade, prenhe de sentidos desconhecidos, tudo isso recoloca a questão: por que não ser total? Como não ser totalmente? O ser humano, assoberbado pelos instantes, deixa-se enamorar pela tentação do absoluto, como o deprimido se deixa seduzir pelas promessas do álcool; um e outro desejam alívio, mas um alívio grandiloqüente. O desejo - desejo de vivência, de sobre-vivência, infla-se e percebe, doravante, apenas a si mesmo, Narciso deslocado de seu terreno original, ideal, e transferido aos domínios do relativo. Nasce o impulso hegemônico da razão ocidental: anular o tempo -, para justificar este desejo: circunscrever a realidade em seu conceito.

Todavia, a suspensão da obviedade, a hesitação do óbvio dos dias, é o reencontro do ser humano com sua indigência, com sua fraqueza congênita, depois e apesar da tentação totalizante, hesitação consciente do grande e sedutor processo totalizante - partículas de bom-senso jogadas ao mundo dos impulsos. Por um momento, em uma doença, em uma crise, em um

25 Cf. SOUZA, R. T. "A vida opaca - meditações sobre a singularidade fracassada", in: OLIVEIRA, N. F.; SOUZA, D. G. (Orgs.). Hermenêutica e filosofia primeira, p. 461-469. 
átimo de desconsolo, cada um é convidado, compelido a bem da sobrevivência possível, a se reencontrar consigo mesmo, com seus limites, com a tensão de sua existência, com seu intervalo próprio. As galáxias a flutuar no espaço infinito, os grãos de areia da praia, a sucessão interminável dos instantes, grãos de areia da existência, são os guardiões modestos da realidade. $\mathrm{Na}$ orgia da totalização e de suas tentações, brilha uma luz pálida: à moda de Pascal, ela tenta relembrar ao ser hipertrofiado o peso dos universos infinitos e da responsabilidade infinita em assumir pretensamente o sentido do todo, em reduzir a realidade a uma fórmula devassável, transparente, sem segredos, sem intimidade.

Última e radical empreitada de clivagem do bloco monolítico em que a vontade se transformou, a suspensão da obviedade que a mortalidade significa oferece a possibilidade de um tempo benigno de reencontro com a própria indigência, com o tempo do Outro, com a infinda multiplicidade de mundos - um tempo de lucidez, uma lucidez à margem da eternidade da Certeza.

A Morte é o limite da Certeza ${ }^{26}$. Antecâmara da implosão totalizante, a suspensão é também a última chance de renunciar a ela, de transformar a morte em algo diferente da oposição à Totalidade de sentido, a saber, em modelo paradigmático da Alteridade absoluta, que realmente não ocupa meu tempo e meu espaço com seu corolário de angústias, ou seja, que não é simplesmente a morte da mônada, mas, sim, radical oportunidade do extremo alterativo. A suspensão dá à mônada uma chance de reencontro com o absurdo em que se transformaram seus dias, ocupados em se tautologizarem indefinidamente, obcecados em truncar o tempo e em restringir o espaço à circunscrição de uma caricatura sua, bloqueando qualquer linguagem, reintroduzindo a racionalidade no bloco monolítico da Razão omnipoderosa, diminuindo as proporções da verdade a algo mais verossímil. A suspensão indica a também a possibilidade de uma profunda crise existencial, a crise fundamental, crise do mundo, no sentido mais próprio do termo: ponderação, possibilidade de julgar o presente, rever e romper com a lógica do passado, preparar o terreno para um futuro que seja algo mais do que a mera reprodução de um presente eterno, bestializado em sua ânsia de eternidade, de completação perfeita. É a possibilidade da maior de todas as crises, a que rompe com o maior de todos os construtos que brotam do universo das tentações humanas, a grande tentação: é a chance da crise - no sentido pleno e original do termo - da Totalidade.

"A morte impede o conhecimento da Totalidade". Esta paráfrase da famosa frase de Rosenzweig dá bem conta da utilidade da morte: impede a absolutização do sentido. Ao modo adorniano, poderíamos dizer: a morte é a expressão última da negatividade da dialética, aquilo que impede que a

26 Cf. ROSENZWEIG, F. Der Stern der Erlösung, p. 3. 
dialética se traia definitivamente a si mesma, mergulhe definitivamente em sua própria sedução.

A morte resolve a crônica adialeticidade da Totalidade que deseja, a um tempo, a finitude $e$ a infinitude: a finitude para se perceber a bem do equilíbrio como total, sem indeterminações, sem a contaminação do mau infinito hegeliano; e a infinitude, para se perceber, da mesma forma, total, sem sobras, sem virtualidades descontroladas - tudo em uma tensão impossível. O generoso ato de morrer reduz saudavelmente a mônada à sua separação original, e reconduz a noção de diferença, filosoficamente tão facilmente neutralizável (o que é a história da filosofia ocidental, em suas linhas hegemônicas, senão a história da tendência a esta neutralização e das subseqüentes reações a esta tendência?) à sua dimensão real. Antídoto da mania de grandeza, o morrer isola as paixões de suas projeções. Desfaz a cortina de fumaça entre o ser e suas produções, entre o ser e o pensar, impedindo a con-fusão com outras sementes de sentido, com outros mundos humanos, com a infinidade deles, impedindo a concentração excessiva de tempos e espaços. Tensão extrema, rompe a tensão artificial que se pode conceber entre os sentidos em nome de um único sentido. A morte permite ao que morre, após seu passeio sideral pelos domínios da eternidade da idéia, o reencontro com o momento, com a variedade, com o descompasso dos únicos, do seu instante único. Acontecimento solitário por excelência, reconduz o ser gregário à sua originalidade separada, ao ter de se ver só em meio ao infinito dos instantes e dos espaços. Grande promessa de sonho, ainda que via negationis, paira por cima do mais delirante dos delírios: conter em si o sentido, reduzir o desejo à sua determinação ao esgotar seu nascedouro - resolver o absoluto.

A morte é, assumindo o sentido levinasiano, a Alteridade prototípica por excelência, agora dada de forma real, alheia à vontade e às demiurgias do ser, e não apenas virtual como em tempo de suspensão. A morte, assim mesmo toscamente substantivada, é primeiro e maior modelo desta Alteridade de tão difícil inteligibilidade; em nenhum campo é a linguagem tão precária quanto neste. A morte reduz a precária atividade humana, seus pequenos estertores diários e seus delírios de grandeza, à passividade absoluta, ou melhor, dá ao termo "passividade" seu conteúdo pleno. A Totalidade não resiste à Morte, porque a morte é o limite de minhas possibilidades, e a Totalidade - a vontade de totalização - é uma possibilidade estritamente minha, do Mesmo em seu delírio especular.

Assim, o essencial do humano é, em última análise, a tensão entre a realidade e a tentação da Totalidade, ou melhor, é o próprio fato inelutável de ter de assumir como sua esta tensão. O fato de que toda onipotência pode ser apenas pensada não afasta do horizonte sua tentação, ou - o que dá na mesma - não derriba a existência humana aos limites da palpabilidade do meramente existente. A tentação da onipotência permanece na ordem do dia, dura ainda, quando todas as esperanças já se diluíram na corrente 
da inefabilidade. Apenas a Alteridade absoluta, signo mortal, faz estalar a grande Certeza que habita o mundo do Sentido único, absoluto, o mundo do todo-poderoso espírito absoluto onde tudo é igual a si mesmo, ao Mesmo, e nada mais, nem a mais remota lembrança, é diferente.

\section{(Interregno - ferindo a solidão)}

“... Se a filosofia é a história que se grava em suas palavras, cada palavra é uma cicatriz ou, porque não há nenhuma garantia de Aufhebung, cada palavra pode ser também uma ferida. [...] A ferida é o buraco do corpo, um buraco não natural, um buraco forjado que implanta a objetividade na câmara-escura do corpo... Novo mecanismo (não digo isso sem certa estranheza): é como se um obturador e um diafragma captassem em seu movimento regulado no tempo a verdade do mundo pela abertura que se faz da invasão abrupta do real. $O$ corpo é aqui mais que olhar como trabalho consciente, mecanismo de captura do inconsciente, liberdade de percorrer com a palavra e o pensamento um lugar experimentado inconscientemente. O trabalho do conceito como trabalho da escrita não se produz pela intenção como produção consciente, mas como deixar-se levar pelo objeto e pelo processo como ação produzida pelo encontro com o objeto. Toda ferida é sofrimento, mas apenas quem foi ferido conhece também o poder da flecha de Eros que inocula no corpo a falta e a criação como superação da dor. Antes disso o corpo é mônada." ${ }^{27}$

\section{Da massa à multiplicidade dos sentidos}

O Outro é uma ferida que rompe a solidão da mônada, ou seja, que coloca seu egoísmo em questão pela multiplicidade qualificada da existência. Os seres humanos - como todos os seres - dão-se em profusão: todo isolamento é impossível. Nenhum tronco portentoso sobrevive se as raízes da árvore e, por conseqüência, seu enraizamento no real, são precários: a vida acha um caminho, e outras plantas mais sólidas, embora menos rígidas, tomam seu lugar. A cada momento, o vital nega a sua subsunção num conceito: é isso que o caracteriza, exatamente, como vitalidade. A multiplicidade do real acontece a despeito das pluralidades formais. Ainda não houve criança que nascesse sem a concorrência de outros; ainda o mais louco delírio não isola alguém tão completamente que este se veja absolutamente só consigo mesmo, dialogando consigo mesmo, agindo somente sobre si mesmo. Nem o mais completo autismo tem a ver apenas consigo mesmo: procura nos objetos a humanidade que não reconhece em si mesmo ou nos outros. A unicidade, característica primigênia de cada ser humano em particular, sua inconfundibilidade, somente se pode estabelecer a partir de sua diferença com relação a outros únicos, e não abstraindo de toda e qualquer diferença em um mundo mental perfeito. Na unicidade está, como em nenhuma outra instância, definitivamente marcada a pluralidade concreta e irredutível dos múltiplos: esta é sua medula.

27 TIBURI, Márcia. Filosofia cinza - a melancolia e o corpo nas dobras da escrita, p. 206-207. 
Deste modo, a subjetividade (sempre entendida como sede da linguagem, das ações humanas) se constitui não como pensavam os mais antigos, prévia à consciência da infinita multiplicação dos mundos humanos, ou por sobre a base de um pensamento em auto-descoberta, de um único Espírito se desdobrando e se completando, de uma Idéia narcisista mirando-se perpetuamente em si mesma, de uma Categoria autofixando-se como raiz de toda e qualquer realidade possível e imaginável; a subjetividade tem consistência e sentido em um mundo infinitamente plural apenas e na medida em que se compõe pluralmente.

Mas o que significa, na prática, compor-se "pluralmente"? Significa centrar no núcleo da composição do plural, na diferença, o seu sentido a um tempo original e mais pleno. É na relação com o outro tempo, com o tempo do outro, não-sincronizévl, que se constrói a subjetividade, e em nenhum outro lugar - por exemplo, não no conforto solipsista ao pé da lareira; é no mais de um, na redefinição árdua, perigosa e constante da diferença, que a subjetividade, a sede da linguagem, de cada um pode vir a ter sentido, e apenas ali.

A dimensão de relação entre os muitos mundos humanos é a dimensão da ética, do agir mútuo e com sentido; o ser humano só pode ser compreendido, enquanto humano, como ético. Sua capacidade de ação, sua subjetividade, se constrói, se conquista não a priori, a partir de seu desabrochar em uma determinada modalidade de existência que, contingente, só se refere à necessidade da eternidade, mas, sim, a partir do difícil e doloroso assumir desta contingência como sua, em contraste permanente com outras contingências - outro nome para a consciência sempre reiterada da diferença real. A construção da subjetividade é um processamento temporal, dá-se no tempo, e não é dada a priori em um apêndice narcisista da eternidade. Esta construção é ética, ou seja, pressupõe mais de um em processo de superação da tentação paralisante da mônada da liberdade burguesa e de suas promessas de felicidade.

Estabelece-se, portanto, um contraste cabal; a consciência solipsista, monádica, é a consciência da eternidade fora do tempo, da Totalidade, da Massa, do sentido único; a consciência ética é a consciência do tempo, do mundo humano, de sua constituição profunda, da socialidade, da multiplicidade infinita de sentidos, tempos e espaços que ainda não aconteceram nem se criaram. É apenas eticamente, na construção da humanidade, da subjetividade ética, que o ser humano, que cada mundo humano pode vir a se encontrar consigo mesmo para além de sua solidão. É a única forma de superação da máxima de Lavoisier: uma relação ética não é uma transformação, mas uma criação improvável nas dobras do tempo que ainda resta.

O ser humano, o indivíduo humano, escândalo das massas, atirado às contingências das quais nenhuma solidez prévia dá conta (nem a solidez ideológica), ocupa o centro de um mundo que nenhum outro ser humano, nem mesmo o mais sábio dos homens, pode realmente perceber como se 
fosse por sua vez o "seu". Nenhum agasalho é suficientemente íntimo para proteger a intimidade exposta às agruras da solidão, do "ter-de-se-ver-só" consigo mesmo, com seus limites, em sua última nudez. O bebê nasce nu, o ser humano dá-se radicalmente nu, exposto ao tempo e ao espaço, à multiplicidade - exposição dramática à contingência, sem prejuízo do fato de ser já, por si só, contingência. E esta exposição às contingências do diaa-dia não pode ser reconstruída em outra situação ou lugar: ela é também única, e não é possível encaixá-la em uma lógica mais ampla, pois ela se constitui em um elemento de exterioridade em relação aos grandes sistemas e esquemas: está fora do grande mundo dos sentidos totalizantes, exterior ao sentido monolítico, existente apesar dos discursos. Face dolorosa da unicidade, o solitário que habita o íntimo do humano cobra um alto preço para suportar sua própria existência: a confrontação de um determinado mundo com outro, com o que não é ele. Só assim ele pode ser ele mesmo.

Não é no nível das realidades pensadas, mas no das realidades vividas, que o Outro deixa suas marcas indeléveis no frágil tecido da superfície da mônada, marcas essas que poderão vir a constituí-la, um dia, como sujeito. Tensão constante entre a unicidade mais radical e a multiplicidade mais indeterminada - eis o intervalo incômodo no qual deve se dar a sobrevivência de cada dia. Mas nenhuma vivência real é intercambiável; apenas, e em uma medida muito restrita, sua ressonância interna no indivíduo, via criação contínua da linguagem, das linguagens, ou seja, da subjetividade. Pois a linguagem, as infinitas linguagens que se entrechocam e se interpenetram em cada momento, com sua riqueza de sugestões, precisões e imprecisões, fala de atos e atos de fala, ditos e não-ditos, dizer que não se cristaliza em ditos, expressões veladas e abertas, silêncios e ruídos, esta linguagem nasce não de um deleite, mas de uma angústia. Na proto-linguagem, no primeiro balbuciar, já a criança protesta por não ser transparente a quem a cerca, por não poder se entregar sem mais à massa, por ter de se expressar, ter de correr o risco de ser ela mesma, ou seja, de ser incompreendida, ter de assumir sua unicidade de uma forma tão inconfundível e indelegável a outrem: assumindo sua própria linguagem, construindo-a para si, desde si, desde sua sociabilidade verdadeira, seus contatos, suas conquistas e decepções, desde seu tempo e seu espaço próprios, circunscritos às suas verdadeiras dimensões. A primeira nota da linguagem é de desconforto: ela gostaria de não ser necessária. Usar a linguagem, ainda que a linguagem da existência, do ocupar um determinado lugar na paisagem, é assumir irremediavelmente o intervalo entre idéia ou paixão perfeita e contingência imperfeita, entre o mundo perfeito e o mundo real, pontificar a existência valendo verbalmente entre os substantivos, sobreviver ao inter-valo que define o campo de ação do intelecto humano, sempre contaminado a priori pelas contingências incômodas do mundo sublunar. Talvez por isso as crianças hesitem tanto em assumir como sua, como criação própria, uma determinada espécie de linguagem algo mais elaborada, ainda que elementar: trata-se 
de um caminho sem retorno. Trilhado que seja em uma pequena extensão, veda já toda ingenuidade, toda crença no imediato de uma comunicação absolutamente desimpedida, toda fé em uma vida perfeitamente fluida, sem hesitações ou desamores. Neste sentido, a linguagem é uma "confissão" de vida, e não de qualquer vida: de vida humana, parcial e circunscrita a uma infinidade de circunstâncias de difícil ou impossível intelecção, em meio às quais é necessário manobrar a bem da específica duração humana.

Enquanto expressão além do tautológico, a linguagem é memória de que se está vivo, é a fonte constante de alívio do peso de viver. Uma linguagem voltada apenas a si mesma significaria, se tal fosse possível, a angústia totalmente concentrada, concentração excessiva de experiências em torno a nós espaciais e temporais, sua pura negação e impossibilidade. Se a demiurgia dos conceitos é uma das armas privilegiadas da Totalidade, sua desfetichização é o estalar do Mesmo, do Todo, da Massa.

As linguagens reais, em processo de desenvolvimento, significam a desinteriorização do íntimo fechado em si mesmo, do idiotismo original, do autismo delirante, e são a fonte privilegiada de contato com outros mundos, ou seja, com outros tempos. Elas se opõem aos conceitos ideais, acoplados a essências eternas, prontos de uma vez para sempre. Ao se pensar, por exemplo, no conceito de "vida", esta "vida" pensada é nada mais do que uma preciosa auxiliar no processo de construção de uma lógica sólida, que funciona a passos largos: nada tem, em verdade, das particularidades que fazem da "vida" uma vida real, que dialoga com o vivente, gloriosa ou esmagadora, a vida que pode levar alguém até mesmo a desejar se suicidar. A vida real dá-se no tempo, enquanto a "vida" conceitual, caricatura daquela, saiu fora do tempo - esta dimensão essencialmente humana da realidade - para poder existir. A vida real é uma questão humana, enquanto a vida ideal é uma questão intelectual. No intervalo tenso, mas possível, entre o conceito e a linguagem, entre o Dito e o Dizer, se desdobra o cotidiano da humanidade, e o que permite que a humanidade perdure apesar de suas idéias. A ponte possível entre as duas dimensões - idealidade e construção do novo real - é por sua vez uma linguagem sempre nova, plenamente consciente de seus próprios limites e precariedades, em um esforço ingente, congênito, de auto-expressão e auto-superação, porque novo é o mundo que o tempo traz.

\section{A liberdade ética}

"A existência em realidade não está condenada à liberdade, mas é investida como liberdade. A liberdade não está nua. Filosofar é remontar aquém da liberdade, descobrir a investidura que liberta a liberdade do arbitrário."

(E. LEVINAS)

A liberdade ética - a solução filosófica da questão teórica da liberdade apresenta-se, fenomenologicamente, sob a forma da responsabilidade pelo 
Outro. Esta responsabilidade é reconhecimento fático da Alteridade enquanto tal.

O essencial do até aqui exposto pode ser articulado da seguinte forma: enquanto a tradição moderna vê a questão da liberdade, de um modo ou de outro, como a expressão de um contrato implícito ou explícito entre mônadas autônomas - pelo menos em termos de um "contratualismo mental", cuja expressão coloquial reza "a minha liberdade cessa onde inicia a liberdade do outro" -, a contemporaneidade que percebe a liberdade como uma questão eminentemente ética repropõe a questão em moldes totalmente diferentes. O que está em jogo não é meramente a liberdade das mônadas, em seu isolamento e auto-suficiência individual, livres para permanecerem presas a si mesmas, em seu trofismo que, em algum ponto, achará, pelo lado do mais forte, em si mesmo a justificação para relativizar este imperativo aparentemente tão estrito, invadindo e determinando, ainda que de forma infinitamente sutil, esta promulgada liberdade formal de outrem. Pois a ética inverteu os termos da questão; à idéia de que "a minha liberdade cessa onde inicia a liberdade do outro", a liberdade eticamente legitimada propõe a máxima: "a minha liberdade começa onde inicia a liberdade do outro", pois a minha liberdade depende, essencialmente, da capacidade de responder ao imperativo da sadia socialidade humana, e não do isolamento livre-subjetivo do indivíduo moderno. E por "sadia socialidade humana" não se entende aqui o estabelecimento de formalidades de ordem contratualista, onde o humano se perde entre seus símbolos e figurações, mas o estabelecimento de uma ordem ética fundamental, onde é impossível a realidade plena da liberdade de alguém - exatamente no sentido atrás descrito, e não como mera substancialidade inefável e dúbia - se esta não se der sob a forma de resposta ética à liberdade de outrem. Trata-se do que Levinas chama, muitas vezes, de "liberdade investida" 28.

Em outros termos, ao reconhecimento fático e inelutável - responsável da Alteridade enquanto tal se pode denominar pedagogia. Pedagogia - a rigor, inviável em um universo de mônadas que sintetizam em si suas identidades e diferenças, por mais altruístas que estas mônadas sejam (pois que se dá no mundo de mônadas exatamente na fresta entre duas afirmações da identidade, no desencontro entre elas, e não no seu encontro) -, que significa, simplesmente, a possibilidade de conceber, hoje, qualquer "gnosiologia" não-violenta, por que significa a inversão da hierarquia da tradição do logos. Aos séculos que sobrepuseram a episteme à relação ética, exige-nos a contemporaneidade uma resposta; esta resposta é a prevalência clara e incontornável da relação ética - ou seja, vontade e ansiedade por justiça - em relação à episteme. $\mathrm{E}$ esta não é apenas uma alternativa possível para os desencontros do presente, mas também a alternativa viável

28 Cf. nosso "Justiça, liberdade e alteridade ética", in: SOUZA, Draiton Gonzaga de; OLIVEIRA, Nythamar Fernandes de. (Orgs.). Justiça e política, Porto Alegre: EDIPUCRS, 2002. 
para as exigências do futuro, nos termos que realmente interessam à sobrevivência: os termos humano-ecológicos.

Desse modo, o conceito "já dito", Dito de uma vez para a eternidade, petrificado pela sua concisão eterna, deve ser, a bem da humanidade, reconquistado pela linguagem, ou seja, deve reassumir seu próprio processo auto-construtivo a partir da sua des-construção. No mundo das idéias não há linguagem: ela não é necessária; existem apenas sentenças analizáveis logicamente. Apenas no mundo do dia-a-dia, repleto de surpresas e novidades, habitado por Outros, é necessário que surja a linguagem, signo da multiplicidade, é imperativo que esta conduza a esperança de superação das ilhas humanas a um termo razoável de encontro com o inusitado. Apenas a linguagem, as infinitas linguagens, oferecem ao assoberbado ser humano a expectativa e a esperança de superação das agruras dos infinitos tempos e espaços, dos "abismos infinitos" de Pascal, que se entremeiam e se entrechocam na difícil constituição do dia-a-dia.

O espaço humano, o mundo humano feito especialidade, oikos, habitação, define-se pela interpenetração de campos de sentido afetivo-existencial: relacional. Humano é o ser que possui real ou potencialmente a capacidade de dilatar e contrair seu espaço de existência, de aproximar abismos e afastar intimidades, de redefinir e reorganizar continuamente seu horizonte de significação, seu sentido vital, o que sobra quando a idéia de vida se exaure. O ser humano habita assim o intervalo que se delimita entre sua corporalidade estrita e o último de seus horizontes concebíveis; ele se constitui como este intervalo, ele o constitui entretempos.

Por sua vez, o tempo concreto, humano, vivido, dá-se como o cruzamento e a interpenetração dos referenciais existenciais que oferecem à duração (mais uma vez em sentido bergsoniano) uma chave interpretativa, um sentido possível, tempo do sentido, é o tempo da consciência, mesmo que ainda não-consciente: a possibilidade de, apesar de tudo e de todos, irromper da massa. A existência concreta é o intervalo entre a inconsciência e a consciência concretas, únicas, irrepetíveis e intraduzíveis, e se teme na morte acima de tudo a inconsciência empírica que segue a condição de morto, a ruptura da oscilação consciência-inconsciência. A analogia entre morte e sono não é gratuita, na medida em que quem dorme, mesmo sonhando, é, ao olhar de quem o vê, uma espécie de consciência de segunda classe. A vida humana cotidiana, existente, é também o intervalo entre duas balizas fixadas no fluxo datável dos acontecimentos, na crono-logia, balizas especiais, assumidas como tais. Dá-se como o intervalo entre duas inconsciências das quais se tem de, necessariamente, tomar consciência eis o essencial do humano. Estar, ser intervalo, e intervalo consciente de seu inter-valer: eis o destino humano por excelência.

Infere-se então facilmente que é a partir do ato pleno de assumir seu próprio intervalo - seu destino - que o ser humano reencontra o caminho da sociabilidade, a consciência feita sociabilidade, pelo rompimento da 
desesperança massiva e de suas promessas hegemônicas e falaciosas. Pois a sociabilidade em si não é congênita: a multiplicidade de seres interagindo não configura realmente a sociabilidade; apenas, como já visto, pode dar origem à massa. A sociabilidade que merece este nome apenas se dá quando se constitui em problema, e problema complexo, para o indivíduo que fala em primeira pessoa; ou seja, em crise de sentido. Ela é um convite, o estranho convite à áspera interpenetração de mundos, de linguagens, o incômodo convite à abdicação da verdade plena. Toda sociabilidade pressupõe, acima de tudo, maturidade, assumir-se maduramente, aceitar ser colocado em questão. Eis o mundo da vida social, da obra, do trabalho, da com-vivência, do viver: o constante colocar em questão da unicidade constituída, pela constituição de uma multiplicidade melhor, embora francamente mais desconfortável. O mundo social, oportunidade de o ser humano reencontrar sua essência social, sua vocação à proximidade, é um processo de crescente aceleração de tempos e interpenetração de espaços, uma aceleração do processo vital; uma de suas características principais é que pode ser negado, em um retorno ao monadismo original dos agentes fortes e decisórios nos processos mais complexos de socialização - por exemplo, na exclusão do diferente de um grupo ou na reificação do trabalhador decaído em mera força de trabalho, em objeto de uso e troca, em peça de máquina diabólica, em um determinado sistema econômico-social. Em última análise, ambos são aspectos de um mesmo fenômeno: o fracasso, por alguma razão, do processo de aproximação e entrecruzamento dos diversos intervalos humanoexistenciais, dos diversos mundos nos quais a construção de uma expressão, de uma linguagem em comum, abortou, fracasso que acontece porque o indiferenciado - a massa - triunfou. A sociabilidade é o mais complexo dos fenômenos humanos, mas também o mais rico; necessita ser recriada exatamente como cada segundo necessita ser respirado; e sua criação e recriação constantes são a única prova vital de que o processo de tomada de consciência da realidade externa está em realmente em curso, e não se confunde com alguma fantasmagoria elucubrada pela mônada para legitimar seu direito ao egoísmo. Pois é com sua radical irrepetibilidade que o ser humano participa, como a totalidade da realidade empírica, da ambigüidade original da existência, intuída bem cedo na história da filosofia: o contraste entre contingência e necessidade, essência e existência, unidade e multiplicidade, idéia e realidade. Impermanência.

De que impermanência se fala? A de ser levado pelo tempo na direção do desconhecido. Não há nenhum status já alcançado que seja tão seguro que possa refrear a voracidade dos momentos sucessivos, infinitamente pequenos, e ao mesmo tempo tão separados e de certa forma tão interpenetrantes, tão fluentes, tão inclementes. A existência, sem o novum da justiça, não é o lugar da clemência. O ser humano é um aventureiro compulsório na terra das surpresas, não pode descansar sem ser surpreendido por um novo momento, um novo frêmito de existência ou a 
morte - exatamente como o viajante em terras desconhecidas se depara a cada instante com situações, coisas e realidades novas, belas ou feias, agradáveis ou perigosas. Nada expressa esta singularidade tão bem quanto o dito amiúde encontrado em velhos relógios: tempus fugit. O grande dilema humano, infinitamente repetido: separar-se, por um átimo, do tempo, mantendo-se nele, durando, apesar de todo o esforço, por força de circunstâncias incontroláveis - suspender-se, por um segundo tão interminável quanto possível, por acima ainda de suas maiores forças e de seus mais ingentes esforços, por acima de todas as determinações nelas e apesar delas. Eis a grande tentação proibida, o desejo de poder olhar para trás sem ser imediatamente devorado pelo presente como pó entre pó "pois o caminho do passado é um caminho que não pode ser trilhado".

É-nos já possível sintetizar o até aqui exposto. O Outro, necessário, inscreve a vida humana enquanto tal no âmbito do realmente possível: liberta a antropologia de sua conotação fabulosa - de fábula - enquanto esta é constituída, na tradição, seja em conceitos puros que habitam apenas um mundo irreal ao qual o ser humano não chega em sua unicidade, seja no finitismo desencantado e ressentido de muitas das filosofias deste século, que nada mais são do que a antevisão do rompimento da Totalidade e a falência de infinitos sonhos de desmedido otimismo e de grandeza. Em ambos os casos, percebe-se alguns elementos comuns: a falência da percepção profunda do tempo - ao procurar refúgio na eternidade, no caso do otimismo, ou ao renunciar até à vivência plena do tempo em interpenetração com outros tempos - ilhota indefesa em mar hostil e revolto, repleto do diferente - no caso do pessimismo desconsolado. Em ambos os casos, também os espaços estão violentados: ou sofrem de uma patológica hipertrofia, invadindo toda a realidade, ou se concentram em um ponto geométrico, sem dimensões, sem interface com nenhuma realidade diferente da ameaça de aniquilação súbita e absoluta. É ao outro que cabe a ruptura do delírio totalizante. Mas que faz o Outro? Traumatiza as certezas, antes de tudo. Pode reconduzir a antropologia a seus termos iniciais: é a vida em sua forma mais inesperada, dá vida, mas vida da Exterioridade e de seu acolhimento. Transforma a ontologia do sentido único em original plurivocidade de linguagens, reconduz em última instância o ser humano a si mesmo, em um reencontro original: ética e nascimento, ética que é nascimento do novo, vivência do tempo e do espaço e refundação dos intervalos em sua infinita tensão. Tensão com sentido de realidade. Entre o Mesmo e o Outro, neste intervalo, ocorre toda a possibilidade de a vida ser humana, ou seja, ter sentido; dá-se tempo ao tempo, tem-se espaço no espaço, a duração vibra, os instantes são vividos e sobrevividos. O restante pertence à ordem da tautologia.

A antropologia somente se reencontra consigo mesma quando a cada instante é restituída sua dignidade, quando ela, em cada momento, é em seu âmago mais essencial a história ética de um encontro, um pequeno ato 
de um infinito drama ético para além de qualquer tautologia, ou seja: ansiedade por justiça. Apenas quando o Outro fala desde si mesmo, quando há a ruptura, ainda que traumática, inesperada e desconfortável da mônada que se constitui no pólo da unidade e unicidade do ser humano, ou seja, quando a unicidade não devora a realidade circundante e se reafirma pela diferença com o que não é ela, aceita a dor da diferença, do instante, da sobrevivência, sem reduzir tal a alguma fórmula, assumindo o limite do instante e destilando o seu próprio mundo humano, sua própria dignidade intervalar, na ansiedade irrevogável por justiça, apenas então é que se pode falar de vida propriamente humana. Pode-se - então - falar de justiça e de dignidade humana.

\section{Dignidade humana}

“A partir de certo ponto não há mais qualquer possibilidade de retorno. $E$ exatamente este o ponto que devemos alcançar."

$(\text { KAFKA, F. })^{29}$

"Só há uma expressão para a verdade: o pensamento que nega a injustiça."

(ADORNO, T. \& HORKHEIMER, M.) ${ }^{30}$

Vida humana é, visceralmente, ansiedade por justiça. Nenhuma criança conhece rebuscadas definições de justiça, mas qualquer criança sabe perfeitamente o que é uma injustiça, quando a sofre ou percebe: é a ferida que, lembrando-a que é humana e está viva, rompe sua solidão monádica. A questão imperiosa da justiça se apresenta à face do tempo como ansiedade por justiça. É à luz da ansiedade por justiça que a dignidade humana deve ser pensada e concebida, hoje. É essa dimensão ansiosa, incompleta, que descola a questão da dignidade humana do essencialismo em que irremediavelmente recai, quando abandonada a um seu conceito fora do mundo de sentido humano que a constitui.

Em outras palavras: o Outro é a condição da socialidade real, aquela que não é uma mera multiplicação de indivíduos e grupos, que é qualidade e não mera quantidade, que é conteúdo e não mera forma, e que pode reduzir as falsas sociabilidades, as sociedades falsas, baseadas na exploração do Outro e da natureza, à sua crua essência perversa, mostrando-as como, simplesmente, a disseminação da Totalidade que se disfarça interminavelmente em conceitos caros à tradição e que se transmuta a cada instante naquilo que o delírio quer ouvir: a paralisia do tempo e do espaço em torno ao pólo único de sentido, a mônada solitária. Quebrar a lógica do sentido único, trincar irrevogavelmente a mônada solitária, é a condição da dignidade humana.

20 In: KAFKA, Franz. Contos, fábulas e aforismos, p. 92.

30 ADORNO, Theodor; HORKHEIMER, Max. Dialética do esclarecimento, p. 204. 
Dignidade humana: direito de ter tempo. A questão da dignidade humana, que passa por uma elaboração extremamente complexa das suas condições antropológicas de possibilidade - da qual todo o texto precedente é pálido testemunho -, desemboca no questionamento do presente como radical questionamento por justiça, ou seja, como radical exigência de promoção de sua alteridade. Dignidade humana é exigência de vida propriamente humana. Mas apenas quando o Outro fala desde si mesmo, quando há a ruptura da mônada que se constitui no pólo egoísta da possibilidade humana, ou seja, quando a unicidade não devora a realidade circundante - não decai em massa - e se reafirma pela diferença com o que não é ela, havendo sido investida em sujeito ético, renunciando às tentações do autismo - do egoísmo da mera individualidade, finalmente autofágica , e aceita a dor da diferença, do instante, da sobrevivência, sem reduzir tal a alguma fórmula, assumindo o limite do instante e destilando o seu próprio mundo humano, sua própria dignidade intervalar, apenas então é que se pode falar de vida propriamente humana - ou seja: de dignidade humana.

Encontro de universos de realidade na ansiedade por justiça - encontro que vale já porque é encontro real. A dignidade humana não é algum tipo de essência, por mais nobre que pareça, mas um acontecimento que não se dá senão em um encontro humano, ou seja, na realização da liberdade ética. Antes da lógica que resolve os problemas para ela mesma, as grandes questões humanas exigem a ética que desarticula e destotaliza definitivamente ser e pensar e provoca todas as respostas humanas aos desafios advindos de encontros reais, individuais, comunitários, sociais, com o Diferente: vontade de justiça. A tentativa de responder à provocação que a Alteridade desde sempre já propõe é a porta de entrada à questão da construção-descoberta do humano, do sentido do humano, do sentido de sua dignidade - ou seja, à sua dignidade a ser preservada e promovida, nessa construção comunitária árdua na qual, graças à paciência do tempo que ainda resta, ainda não se chegou à última palavra.

\section{Referências}

ADORNO, T. Palavras e sinais - modelos críticos II. Petrópolis: Vozes, 1995.

. Minima moralia. São Paulo: Ática, 1993.

. Negative Dialektik. Frankfurt a. M: Suhrkamp, 1988.

. Teoria estética. São Paulo: Martins Fontes, s/d .

. Prismas - crítica cultural e sociedade. São Paulo: Ática, 1998.

ADORNO, T;; HORKHEIMER, Max. Dialética do esclarecimento. Rio de Janeiro: J. Zahar, 1985.

KAFKA, F. Contos, fábulas e aforismos. Rio de Janeiro: Civilização Brasileira, 1993.

LEVINAS, E. Humanismo do outro homem. Petrópolis: Vozes,

. Le temps et l'Autre. Montpellier: Fata Morgana, 1979.

LUIJPEN, W. Introdução à fenomenologia existencial. São Paulo: EPU-EDUSP, 1973. 
MALAPARTE, C. A pele. Rio de Janeiro: Editora Civilização Brasileira, 1985.

ROSENZWEIG, F. Zweistromland - Kleinere Schriften zu Glauben und Denken (Gesammelte Schriften III). Dordrecht/Boston/Lancaster: Martinus Nijhoff Publishers, 1984.

. Der Stern der Erlösung. Frankfurt am Main: Suhrkamp, 1996.

SOUZA, R. T. de. Totalidade \& desagregação - sobre as fronteiras do pensamento e suas alternativas. Porto Alegre: EDIPUCRS, 1996.

. O tempo e a máquina do tempo - estudos de filosofia e pós-modernidade. Porto Alegre: EDIPUCRS, 1998.

. Sujeito, ética e história - Levinas, o traumatismo infinito e a crítica da filosofia ocidental. Porto Alegre: EDIPUCRS, 1999.

. Existência em decisão - uma introdução ao pensamento de Franz Rosenzweig. São Paulo: Perspectiva, 1999.

2000.

. Sentido e alteridade-dez ensaios sobre o pensamento de E. Levinas. Porto Alegre: EDIPUCRS,

. Metamorfose e extinção - sobre Kafka e a patologia do tempo. Caxias do Sul: EDUCS, 2000.

. Ainda além do medo - filosofia e antropologia do preconceito. Porto Alegre: DaCasaPalmarinca, 2002. 2003.

. Sobre a construção do sentido - o pensar e o agir entre a vida e a filosofia. São Paulo: Perspectiva,

Razões plurais - itinerários da racionalidade ética no século XX: Adorno, Bergson, Derrida, Levinas, Rosenzweig. Porto Alegre: EDIPUCRS, 2004.

. Fontes do humanismo latino - a condição humana no pensamento filosófico moderno e contemporâneo. Porto Alegre: EDIPUCRS, 2004.

. Em torno à diferença - aventuras da alteridade na complexidade da cultura contemporânea.

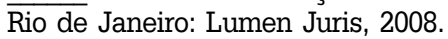

.Humanismo e alteridade. A filosofia frente à radicalidade do desafio humano. In: PAVIANI, $\bar{J}$.; DAL RI Jr., A. (Orgs.). Humanismo latino no Brasil de hoje. Belo Horizonte: Editora da PUC-MG, 2001. p. 81-95.

. A vida opaca - meditações sobre a singularidade fracassada. In: OLIVEIRA, N. F.;

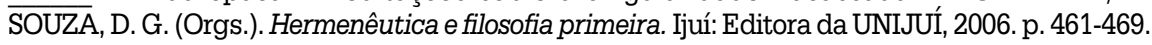

. Justiça, liberdade e alteridade ética. Sobre a questão da radicalidade da justiça desde o pensamento de E. Levinas. In: VERITAS - Revista de Filosofia, v. 46, n. 2, p. 265-274, jun. 2001.

. A dignidade da pessoa humana: uma visão contemporânea. In: Filosofazer, Passo Fundo, ano XIV, n. 26, p. 7-36, 2005-II.

. A dignidade da pessoa humana. In: KIPPER, D. J. (Org.). Ética: teoria e prática - uma visão multidisciplinar. Porto Alegre: EDIPUCRS, 2006. p. 100-132.

. Nós e os outros. Sobre a questão do humanismo, hoje. In: PAVIANI, Jayme; DAL RI Jr.

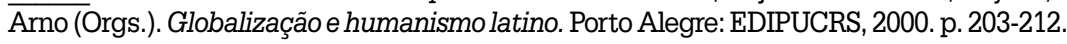

. O corpo do tempo - um exercício fenomenológico. In: SOUZA, Ricardo Timm de; OLIVEIRA, Nythamar Fernandes de. (Orgs.). Fenomenologia hoje II-significado e linguagem. Porto Alegre: EDIPUCRS, 2002.

SUSIN, L. C. O homem messiânico. Uma introdução ao pensamento de Emmanuel Levinas. Porto Alegre; Petrópolis: EST-Vozes, 1983.

TIBURI, M. Filosofia cinza - a melancolia e o corpo nas dobras da escrita. Porto Alegre: Escritos Editora, 2004. 